\title{
Maternal diet composition alters serum steroid and free fatty acid concentrations and vaginal $\mathrm{pH}$ in mice
}

\author{
J J Whyte', A P Alexenko ${ }^{2}$, A M Davis ${ }^{1,2}$, M R Ellersieck ${ }^{3}$, E D Fountain ${ }^{1}$ and C S Rosenfeld ${ }^{1}$ \\ Departments of ${ }^{1}$ Biomedical Sciences, ${ }^{2}$ Animal Sciences, Christopher S. Bond Life Sciences Center, ${ }^{3}$ Food Systems and Bioengineering, Agriculture Experiment \\ Station-Statistics, University of Missouri-Columbia, Columbia, Missouri 65211, USA \\ (Requests for offprints should be addressed to C S Rosenfeld; Email: rosenfeldc@missouri.edu)
}

\begin{abstract}
We examined the effects of three maternal diets (very high fat (VHF), low fat (LF), and control (Purina 5015)) on serum steroids, free fatty acids (FFA), and vaginal $\mathrm{pH}$ in National Institutes of Health Swiss mice. Females were fed (VHF, $n=33$; LF, $n=33$; $5015, n=48$ ) from 4 to 16 weeks of age. Following breeding, female serum was collected at 0.5 (pre-implantation, early diestrus) or 8.5 (post-implantation, mid-diestrus) days post-coitus (dpc). The serum concentrations of $17 \beta$-estradiol, testosterone, progesterone, and FFA were analyzed at both collection points, and vaginal $\mathrm{pH}$ at $0.5 \mathrm{dpc}$. Striking differences in steroids and FFA were observed at $0.5 \mathrm{dpc}$ among the groups. Estradiol was higher in the VHF $(14 \cdot 1 \pm 3.0 \mathrm{pg} / \mathrm{ml})$, compared with LF mice $(5 \cdot 2 \pm 2 \cdot 3 \mathrm{pg} / \mathrm{ml} ; P \leq 0 \cdot 05)$. In contrast, $0 \cdot 5 \mathrm{dpc}$ testosterone was lower in the VHF $(10.5 \pm 3.0 \mathrm{pg} / \mathrm{ml})$ versus the LF group
\end{abstract}

$(32.7 \pm 8.4 \mathrm{pg} / \mathrm{ml} ; P \leq 0 \cdot 05)$. At $8.5 \mathrm{dpc}$, progesterone was higher in the VHF $(89 \cdot 6 \pm 6 \cdot 7 \mathrm{ng} / \mathrm{ml})$ versus the 5015 group $(60 \cdot 1 \pm 4.9 \mathrm{ng} / \mathrm{ml} ; P \leq 0 \cdot 05)$. VHF mice had higher FFA concentrations at $0.5 \mathrm{dpc}(1.0 \pm 0.2 \mathrm{mmol} / \mathrm{l})$ than LF and control mice $(0.5 \pm 0 \cdot 1$ and $0.6 \pm 0.1 \mathrm{mmol} / 1$ respectively; $P \leq 0 \cdot 05)$. At $8.5 \mathrm{dpc}$, VHF females had higher serum FFA $(0 \cdot 8 \pm 0 \cdot 1 \mathrm{mmol} / \mathrm{l})$ than LF and control females $(0 \cdot 4 \pm 0 \cdot 1$ and $0.6 \pm 0.1 \mathrm{mmol} / 1 ; P \leq 0 \cdot 05)$. Mean vaginal $\mathrm{pH}$ of VHF females $(6 \cdot 41 \pm 0 \cdot 09)$ was lower than 5015 females $(6 \cdot 76 \pm$ $0 \cdot 10 ; P \leq 0 \cdot 05)$. These diet-induced alterations in serum steroid and FFA concentrations might affect several reproductive processes, including preferential fertilization by one class of sperm over the other and sex bias in pre- and post-implantational embryonic development.

Journal of Endocrinology (2007) 192, 75-81

\section{Introduction}

For several years, this laboratory has been interested in the effects maternal diet can have on offspring sex ratio Rosenfeld et al. 2003. Many past and present reports have suggested that diet, particularly one enriched with either saturated or unsaturated fatty acids, can alter serum steroid concentrations in a variety of species, including rodents, food animals, and humans (Talavera et al. 1985, Hilakivi-Clarke et al. 1996, Woods et al. 1996, Hilakivi-Clarke et al. 1997, Dorgan et al. 2003). Thus, as a potential aside, we were interested in examining the effects of three diets: very high fat/low fat (VHF, LF; Research Diets, New Brunswick, NJ, USA), and Purina 5015 chow-based diet (Purina, St Louis, MO, USA; see Table 1) on serum steroid concentrations and free fatty acids. While the mechanisms underlying diet-induced alteration of offspring sex ratio are likely complex, any diet-induced differences in steroid concentration may help to elucidate how diet skews offspring sex ratio.

Dietary fat can influence the expression of enzymes that metabolize sex steroid hormones (Zhou et al. 2005, Dieudonne et al. 2006). Adipose tissue is an important site of steroid hormone biosynthesis (Siiteri 1987, Belanger et al. 2002, Simpson 2003, Dieudonne et al. 2006). Moreover, ovarianderived $\Delta 4$ androstenedione and testosterone can be aromatized in adipose tissue to estrone and estradiol respectively (Lambrinoudaki et al. 2006). An additional potential mechanism of dietary influence on sex steroid concentration relates to the status of cholesterol as a precursor to steroid hormones. Diet can influence serum cholesterol (Menotti 1999) and high cholesterol is correlated with high serum androgen and estrogen concentrations (Shelley et al. 1998, Kumagai et al. 2001). Past studies in rodents, cattle, and humans have indicated that diet might underpin changes in serum hormonal concentrations, including testosterone and estrogen (Killen et al. 1989, Wynn \& Wynn 1993, Dorgan et al. 1996, Hilakivi-Clarke et al. 2002, Dorgan et al. 2003, FernandezTwinn et al. 2003). Female rats fed a diet enriched with n-3 polyunsaturated fatty acids had a $48 \%$ increase in serum concentrations of $17 \beta$-estradiol compared with rats fed a diet enriched with n-6 fatty acids (Hilakivi-Clarke et al. 2002). Similarly, female rats fed a low protein diet had a significant increase in $17 \beta$-estradiol compared with those fed a control diet (Fernandez-Twinn et al. 2003). Nutritionally restricted heifers have decreased serum estrogen concentrations at day 200 of pregnancy compared with larger, non-food restricted heifers (Killen et al. 1989). A high saturated fat diet induces an increase in estrogen, estrone, and dehydroepiandrosterone sulfate concentrations in women (Dorgan et al. 1996, Nagata et al. 
2005). A controlled clinical trial revealed that girls fed a low fat (LF) diet exhibited higher serum testosterone concentrations during the luteal phase of the cycle but lower estradiol concentrations (Dorgan et al. 2003).

In the light of these previous studies, we have examined the serum concentrations of testosterone, estrogen, progesterone, and free fatty acids (FFA) in female mice fed a predominantly lard diet (which skews the offspring sex ratio to males), a LF/high carbohydrate diet (which skews the ratio towards females), and a chow-based control diet (which gives rise to roughly equivalent numbers of male and female pups). Our underlying hypothesis was that diet might alter various serum steroid concentrations, which in turn may influence the reproductive tract environment, such as vaginal $\mathrm{pH}$, at copulation or during embryonic development to favor the success of one sex over the other.

\section{Materials and Methods}

\section{Animal breeding and diet conditions}

NIH Swiss mice (Mus musculus) were bred and maintained in the University of Missouri's Animal Science Research Center. All the experiments were carried out according to the NIH Guidelines for the Care and Use of Laboratory Animals and were approved by the University of Missouri's Animal Care and Use Committee. Mice were housed in polysulfone cages (Uni Cage, Siloam Springs, AR, USA; dimensions: $18 \cdot 4 \mathrm{~cm}$ $\mathrm{W} \times 29 \cdot 2 \mathrm{~cm} \mathrm{D} \times 12 \cdot 7 \mathrm{~cm} \mathrm{H})$. During non-breeding periods, four female mice were housed per cage, and during breeding, two females were housed with one male.

All mice used in this study were NIH Swiss and were bred and assigned to diet groups as described previously (Rosenfeld et al. 2003). In December 2004 (Study 1), 8 to 10-week-old P1 NIH Swiss female mice (Harlan, Madison, WI, USA) were bred to stud males. After weaning at 21 days, 18 female offspring were maintained on a regular chow diet, Purina 5015 (5015), until they were 30 days of age and then randomly assigned to three groups and fed ad libitum the control Purina $5015(n=10)$, low fat (LF; $n=4)$, or very high fat (VHF; $n=4)$ diets throughout the study. The females were bred at 20 weeks of age to stud NIH Swiss males ( $\approx 12$-week-old). A replicate study was initiated 2 weeks after beginning the first to provide a total of 13 mothers each in the LF and VHF dietary groups and 28 mothers in the 5015 dietary group. To increase the sample size in each diet group, two additional experiments of identical design were initiated in October 2005 (Study 2; $n=6$ females per group, 16 weeks on diets) and December 2005 (Study $3 ; n=14$ females per group, 16 weeks on diets) to provide an overall total of 33 females in the LF and VHF diet groups, and 48 females in the 5015 diet groups.

Conception was assessed by the presence of a coital plug (the day of the coital plug being scored as 0.5 days post-coitus (dpc)), and females were assessed to be pregnant by the presence of either pre-implantational embryos in the oviduct $(0.5 \mathrm{dpc})$ or implanted conceptuses in the uterine wall $(8 \cdot 5 \mathrm{dpc})$. Vaginal $\mathrm{pH}$ was determined at $0.5 \mathrm{dpc}$ in all females as described in the next section. Females were then randomly assigned to one out of the two study groups. In the first group, pregnant females (VHF, $n=15$; LF, $n=14 ; 5015, n=23$ ) were killed after $\mathrm{pH}$ determination by $\mathrm{CO}_{2}$ inhalation and subsequent cervical dislocation. Collection of serum for steroid hormone and FFA concentrations was performed immediately. In the second group (VHF, $n=11$; LF, $n=17 ; 5015, n=17$ ), vaginal $\mathrm{pH}$ was determined, and females were housed in separate cages and maintained on their assigned diet until $8.5 \mathrm{dpc}$. At this point, females were killed for serum collection as described above.

\section{Vaginal $p H$ determination}

Vaginal $\mathrm{pH}$ measurements were performed by using an MI-413 Needle Combination $\mathrm{pH}$ microelectrode (Microelectrodes Inc., Bedford, NH, USA) with electrode diameter of $16 \mathrm{G}$ needle and BASIC pH meter (Denver Instruments, Denver, Colorado, USA). Mice were immobilized in a restrainer made from a $50 \mathrm{ml}$ Falcon centrifuge tube (Becton Dickinson and Company, Franklin Lakes, NJ, USA). Each mouse was placed inside the tube and fixed with the cap from the same tube with $15 \mathrm{~mm}$ diameter hole in it, thereby allowing access to the tail and the vaginal opening. Presented data are averages from at least five independent measurements on each mouse.

\section{Blood collection and serum preparation}

A non-heparinized whole blood sample was obtained by cardiac puncture, and the microfuge tubes containing the whole blood were placed on ice for $30 \mathrm{~min}$ to permit clotting. The samples were centrifuged at $7500 \mathrm{~g}$ for $20 \mathrm{~min}$. The resulting serum fraction was collected and transferred to a new autoclaved microcentrifuge tube and centrifuged at $7500 \mathrm{~g}$ for $3 \mathrm{~min}$ to remove further traces of clotted blood. Aliquots of serum for $17 \beta$-estradiol, progesterone, and testosterone enzyme immunoassay (EIA) were stored at $-20^{\circ} \mathrm{C}$, and aliquots of serum for FFA determination were stored at $-80^{\circ} \mathrm{C}$.

\section{Estradiol assays}

Circulating serum concentrations of $17 \beta$-estradiol were analyzed by using a modified EIA procedure initially described by Perry et al. (2004). Duplicate samples $(50 \mu \mathrm{l})$ were extracted with $2 \mathrm{ml}$ methyl-tert-butyl ether (HPLC grade; Fisher Chemical Co., Fair Lawn, NJ, USA) for 2 min on a vortexer. Samples were frozen in a dry ice-methanol bath. The solvent fraction was decanted into $12 \times 75 \mathrm{~mm}$ borosilicate glass tubes and dried under a stream of nitrogen gas. Extracts were reconstituted in $50 \mu \mathrm{l}$ estradiol-free control serum.

Estradiol EIA kits and reagents were obtained from Diagnostic Systems Laboratories, Inc. (DSL; Webster, TX, USA) and Cayman Chemical (Ann Arbor, MI, USA). The assays were performed according to the manufacturer's instructions. All extracted samples were run in duplicate on a 96-well plate and measured on a Bio-Tek Synergy HT plate reader at 450 (DSL) or $412 \mathrm{~nm}$ (Cayman) absorbance (Bio-Tek 
Instruments Inc., Winooski, VT, USA). Estradiol concentrations in samples were determined based on a $17 \beta$-estradiol standard curve (DSL: 0-2000 pg/ml; $r^{2}=0 \cdot 98$; Cayman: $\left.7 \cdot 8-1000 \mathrm{pg} / \mathrm{ml} ; r^{2}=0 \cdot 97\right)$. Concentrations of $17 \beta$-estradiol in two duplicate control standards $(250 \pm 100$ and $1000 \pm$ $350 \mathrm{pg} / \mathrm{ml}$; DSL) were determined within the specified margin of error. Intra- and inter-assay coefficients of variation for the Cayman $17 \beta$-estradiol assay were $3 \cdot 3$ and $7 \cdot 6 \%$ respectively. Intra- and inter-assay coefficients of variation for the DSL $17 \beta$-estradiol assay were $4 \cdot 6$ and $11 \cdot 2 \%$ respectively.

\section{Progesterone and testosterone assays}

Concentrations of free progesterone and testosterone were determined by EIA with unextracted serum samples. Progesterone and testosterone EIA kits and reagents were obtained from Diagnostic Systems Laboratories, Inc. Each assay was run according to the manufacturer's protocols. All the serum samples $(50 \mu \mathrm{l})$ were run in duplicate and measured on a Bio-Tek Synergy HT plate reader at $450 \mathrm{~nm}$ absorbance (Bio-Tek Instruments Inc.). Serum progesterone concentrations were determined based on a five-point progesterone standard curve $\left(0 \cdot 3-80 \mathrm{ng} / \mathrm{ml} ; r^{2}=0 \cdot 99\right)$. Concentrations of progesterone in two duplicate control standards $(1 \pm 0.3$ and $7 \pm 2 \mathrm{ng} / \mathrm{ml}$; DSL) were determined within the specified margin of error. Testosterone concentrations in samples were determined based on a six-point testosterone standard curve $\left(5-3000 \mathrm{pg} / \mathrm{ml} ; r^{2}=0.99\right)$. Concentrations of testosterone in two duplicate control standards $(50 \pm 15$ and $250 \pm 50 \mathrm{pg} / \mathrm{ml}$; DSL) were determined within the specified margin of error. Intra- and inter-assay coefficients of variation for the testosterone assay were $3 \cdot 0$ and $10 \cdot 5 \%$ respectively. Intraand inter-assay coefficients of variation for the progesterone assay were $3 \cdot 7$ and $12 \cdot 6 \%$ respectively.

\section{Serum free fatty acids}

Concentrations of FFA were measured in triplicate using an enzymatic assay and according to the manufacturer's instructions (Wako Chemicals, Richmond, VA, USA) and other published methods (Parks et al. 2005). Concentrations of FFA were determined based on a four-point FFA standard curve $\left(0-1 \mathrm{mmol} / \mathrm{l} ; r^{2}=0 \cdot 99\right)$. The intra- and inter-assay coefficients of variation were 16.9 and $9.9 \%$ respectively.

\section{Statistical analyses}

The results are expressed as the mean \pm s.E.M. Effects of diet on serum steroids and FFA were examined by ANOVA as a $2 \times 3$ factorial arrangement with time of serum collection and diet as factors respectively. Effect of diet on vaginal $\mathrm{pH}$ was tested by using one-way ANOVA. Distributions of continuous variables were tested for normality by use of the Kolmogorov-Smirnov test. Endpoints with heterogeneous variance were logarithmically transformed. Post hoc treatment effects were tested by using Fisher's least significant difference mean separation test. Pearson's product moment correlation was employed to determine the relationship between serum steroid concentrations and maternal weight and embryo number. The $n$ used for the analyses varied for the different analyses because for some samples there was not enough serum to perform all of the EIA for the steroids and the FFA. Statistical significance was set at the 0.05 level (SAS 1988).

\section{Results}

\section{Vaginal $p H$}

At $0.5 \mathrm{dpc}$, female NIH Swiss mice in the VHF diet group had significantly lower vaginal $\mathrm{pH}(6 \cdot 41 \pm 0 \cdot 09 ; n=16)$ compared with the 5015 control group $(6 \cdot 76 \pm 0 \cdot 10 ; n=19$; ANOVA, $P \leq 0 \cdot 05)$. However, this statistical difference did not extend to the LF $(6 \cdot 61 \pm 0 \cdot 08 ; n=19)$ diet group.

\section{Maternal body weights}

As was observed in a previous study (Rosenfeld et al. 2003), the mice tolerated the different diet conditions well, including the high lard content of the VHF diet. Maternal body weights over the 16-week dietary treatment period are displayed in Fig. 1. The greatest increase in body weight over time was seen in VHF-fed females, but this difference was only significant in Study 3 (Table 1; ANOVA; $P \leq 0 \cdot 05$ ). Despite the lack of maternal body weight difference among diet treatments, in general, body composition was visibly different during dissection, with VHF-fed females having larger amounts of visceral fat.

\section{Serum estradiol}

Mean concentrations of extracted serum estradiol at $0.5 \mathrm{dpc}$ in mice fed the VHF diet $(14.1 \pm 3.0 \mathrm{pg} / \mathrm{ml}$; Fig. 2) were significantly higher than mice fed the LF $(5 \cdot 2 \pm 2 \cdot 3 \mathrm{pg} / \mathrm{ml}$; $P \leq 0 \cdot 05)$ and 5015 control $(8 \cdot 2 \pm 2 \cdot 3 \mathrm{pg} / \mathrm{ml} ; P \leq 0 \cdot 05)$ diets. At $8.5 \mathrm{dpc}$, the relative concentrations of extracted serum estradiol in mice-fed VHF and LF diets appeared to be inverted compared with the $0.5 \mathrm{dpc}$ means, but did not differ statistically at this collection time point (Fig. 2). Extracted serum estradiol at $0.5 \mathrm{dpc}$ was correlated with breeding maternal body weight $(\mathrm{g})$ when the three diet groups for all the study times were analyzed $(r=0 \cdot 55 ; n=44 ; P \leq 0 \cdot 05)$. No correlation with serum estradiol was detected for breeding maternal body weight at $8.5 \mathrm{dpc}$.

\section{Serum testosterone}

Mice fed a LF diet had significantly higher mean serum testosterone concentrations at $0.5 \mathrm{dpc}(32.7 \pm 8.4 \mathrm{pg} / \mathrm{ml})$ compared with both VHF $(10.5 \pm 3.0 \mathrm{pg} / \mathrm{ml})$ and 5015 control $(12.9 \pm 3.4 \mathrm{pg} / \mathrm{ml})$-fed mice (Fig. 2; ANOVA; $P \leq 0 \cdot 05$ ). In contrast, at $8.5 \mathrm{dpc}$ (Fig. 2), VHF-fed mice had significantly higher serum testosterone concentrations $(77 \cdot 8 \pm 27 \cdot 8 \mathrm{pg} / \mathrm{ml})$ compared with 5015 control-fed mice $(51 \cdot 3 \pm 40 \cdot 7 \mathrm{pg} / \mathrm{ml} ;$ ANOVA; $P \leq 0 \cdot 05)$. However, 


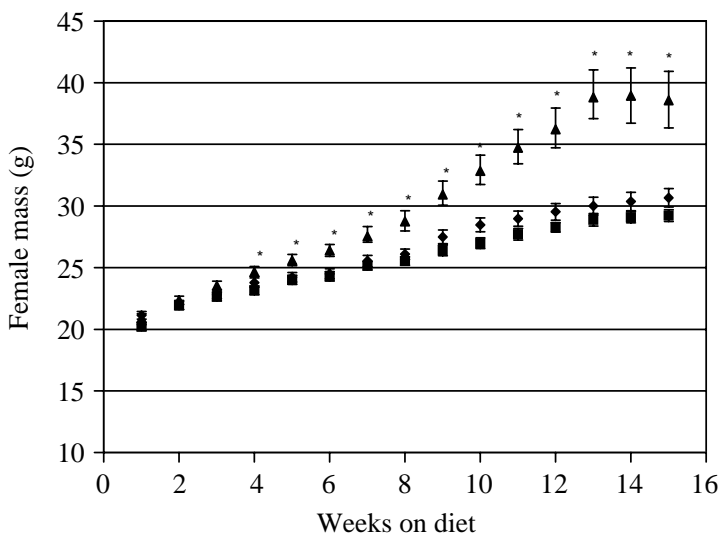

Figure 1 Changes in mean maternal body weight ( \pm S.E.M.) of mice until breeding on the $\operatorname{VHF}(\boldsymbol{\Lambda} ; n=23), \operatorname{LF}(\boldsymbol{\square} ; n=28)$, and 5015 control $(\forall n=35)$ diets. The data are from three studies, with females maintained on diets for 16 weeks starting at 30 days of age. Significant weight difference of VHF females from LF and control groups is denoted by asterisks (ANOVA; $P<0 \cdot 05$ ).

testosterone concentrations in LF-fed mice at $8 \cdot 5 \mathrm{dpc}(62 \cdot 3 \pm$ $27 \cdot 7 \mathrm{pg} / \mathrm{ml}$ ) did not differ from the other two groups. As was the case with serum estradiol, serum testosterone at $0.5 \mathrm{dpc}$ was negatively correlated with breeding maternal body weight $(\mathrm{g})$ when the three dietary groups for all study times were analyzed $(r=-0 \cdot 38 ; n=43 ; P \leq 0 \cdot 05)$. No relationship existed between $8.5 \mathrm{dpc}$ serum testosterone concentration and maternal breeding weight.

\section{Serum estradiol/testosterone $(\mathrm{E} / \mathrm{T})$ ratio}

The ratio of extracted serum estradiol to serum testosterone in individual mice was on average greater than one for females on the VHF diet at $0 \cdot 5 \mathrm{dpc}(23 \cdot 3 \pm 11 \cdot 6 ; n=12)$ and less than

Table 1 Effect of control (5015), LF, and VHF diets on embryo number and maternal weight (g) of female mice aged 20 weeks at breeding (mean \pm S.E.M.)

\begin{tabular}{|c|c|c|}
\hline & Diet & Maternal weight ( $g ; 20$ weeks) \\
\hline \multicolumn{3}{|l|}{ Breeding date } \\
\hline \multirow[t]{3}{*}{ Study 1 (July 2005) } & 5015 & $29 \cdot 5 \pm 0 \cdot 7(n=22)$ \\
\hline & LF & $29 \cdot 1 \pm 0 \cdot 9(n=10)$ \\
\hline & VHF & $32 \cdot 5 \pm 1 \cdot 4(n=9)$ \\
\hline \multirow[t]{3}{*}{ Study 2 (February 2006) } & 5015 & $29 \cdot 3 \pm 3 \cdot 6(n=4)$ \\
\hline & LF & $26 \cdot 8 \pm 0 \cdot 7(n=4)$ \\
\hline & VHF & $32 \cdot 5 \pm 4 \cdot 0(n=4)$ \\
\hline \multirow[t]{3}{*}{ Study 3 (April 2006) } & 5015 & $34 \cdot 2 \pm 5 \cdot 6(n=9)^{\mathrm{a}}$ \\
\hline & LF & $30 \cdot 0 \pm 2 \cdot 2(n=14)^{\mathrm{a}}$ \\
\hline & VHF & $47 \cdot 0 \pm 11 \cdot 8(n=10)$ \\
\hline \multirow[t]{3}{*}{ Combined } & 5015 & $30 \cdot 7 \pm 0 \cdot 7(n=35)^{\mathrm{a}}$ \\
\hline & LF & $29 \cdot 2 \pm 0 \cdot 5(n=28)^{\mathrm{a}}$ \\
\hline & VHF & $38 \cdot 6 \pm 2 \cdot 3(n=23)$ \\
\hline
\end{tabular}

Three identical study designs conducted on different dates are analyzed separately and in combination. Embryo number counts include both 0.5 and 8.5 dpc embryos collected. Lowercase letters denote significant differences among dietary treatments (ANOVA; $P \leq 0 \cdot 05$ ). one for females on the LF diet at $0 \cdot 5 \mathrm{dpc}(0 \cdot 2 \pm 0 \cdot 1 ; n=9)$. The mean LF female $E / T$ ratio was significantly lower than both the VHF and the 5015 ratios (ANOVA; $P \leq 0 \cdot 05$ ) at $0.5 \mathrm{dpc}$. The mean $E / T$ ratios for the three dietary treatments at $8.5 \mathrm{dpc}$ differed significantly (ANOVA; $P \leq 0.05$ ), but in contrast to the $0.5 \mathrm{dpc}$ results, the $E / T$ ratio in individual mice was generally less than one for females on the VHF diet $(0 \cdot 2 \pm 0 \cdot 1 ; n=8)$ and greater than one for females on the LF diet $(5 \cdot 5 \pm 3 \cdot 8 ; n=11)$. At $0 \cdot 5$ and $8 \cdot 5 \mathrm{dpc}$, mean $E / T$ ratios for mice on the 5015 control diets were $3 \cdot 2 \pm 1 \cdot 7(n=17)$ and $1 \cdot 7 \pm 0 \cdot 6(n=12)$ respectively.

\section{Serum progesterone}

Serum progesterone at $0.5 \mathrm{dpc}$ did not differ among the dietary groups (Fig. 2), but the concentration of this steroid was inversely related to maternal body weight at the time of breeding $(r=-0 \cdot 36, n=44, P \leq 0 \cdot 05)$. At $8.5 \mathrm{dpc}$, (Fig. 2), VHF-fed mice had significantly higher serum progesterone concentrations $(89.6 \pm 6 \cdot 7 \mathrm{ng} / \mathrm{ml})$ compared with 5015 control-fed mice $(60 \cdot 1 \pm 4 \cdot 9 \mathrm{ng} / \mathrm{ml}$; ANOVA; $P \leq 0 \cdot 05)$. In contrast to the negative correlation at $0.5 \mathrm{dpc}$, a significant positive relationship existed between maternal body weight at the time of breeding and serum progesterone concentration at $8 \cdot 5 \mathrm{dpc}(r=49, n=34, P \leq 0 \cdot 05)$.

\section{Serum free fatty acids (FFA)}

Mice in the VHF diet group had an elevated mean concentration of FFA at $0.5 \mathrm{dpc}$ (Fig. $2 ; 1 \cdot 0 \pm 0.2 \mathrm{mmol} / \mathrm{l}$ ) compared with both the LF and the 5015 control diet groups $(0.5 \pm 0 \cdot 1$ and $0.6 \pm 0.0$ respectively; ANOVA; $P \leq 0.05)$ This same pattern of concentrations was observed in the different dietary groups at $8.5 \mathrm{dpc}$, with significant differences among all the three groups (Fig. 2; ANOVA; $P \leq 0 \cdot 05$ ). No relationship between FFA and maternal body weight at breeding was observed at either 0.5 or $8.5 \mathrm{dpc}(n=48$ and 37 respectively).

\section{Discussion}

Herein, we have examined the influence of diet on some reproductive variables in mice, including serum concentrations of sex steroids and vaginal $\mathrm{pH}$, and discovered that diet can influence these parameters. The interactions between diet and circulating steroid hormone concentrations were complex. The VHF diet increased serum estrogen concentrations relative to the other dietary treatments at $0.5 \mathrm{dpc}$, but not at $8.5 \mathrm{dpc}$. Previous studies have shown that serum estrogen concentrations are highest at proestrus and decline during pregnancy (McCormack \& Greenwald 1974, Nelson et al. 1992, Walmer et al. 1992; reviewed in Overpeck et al. 1978). The higher amount of estradiol in the mice on the VHF diet compared with the other diet groups could be related to the amount of accumulated body fat in the mice. 

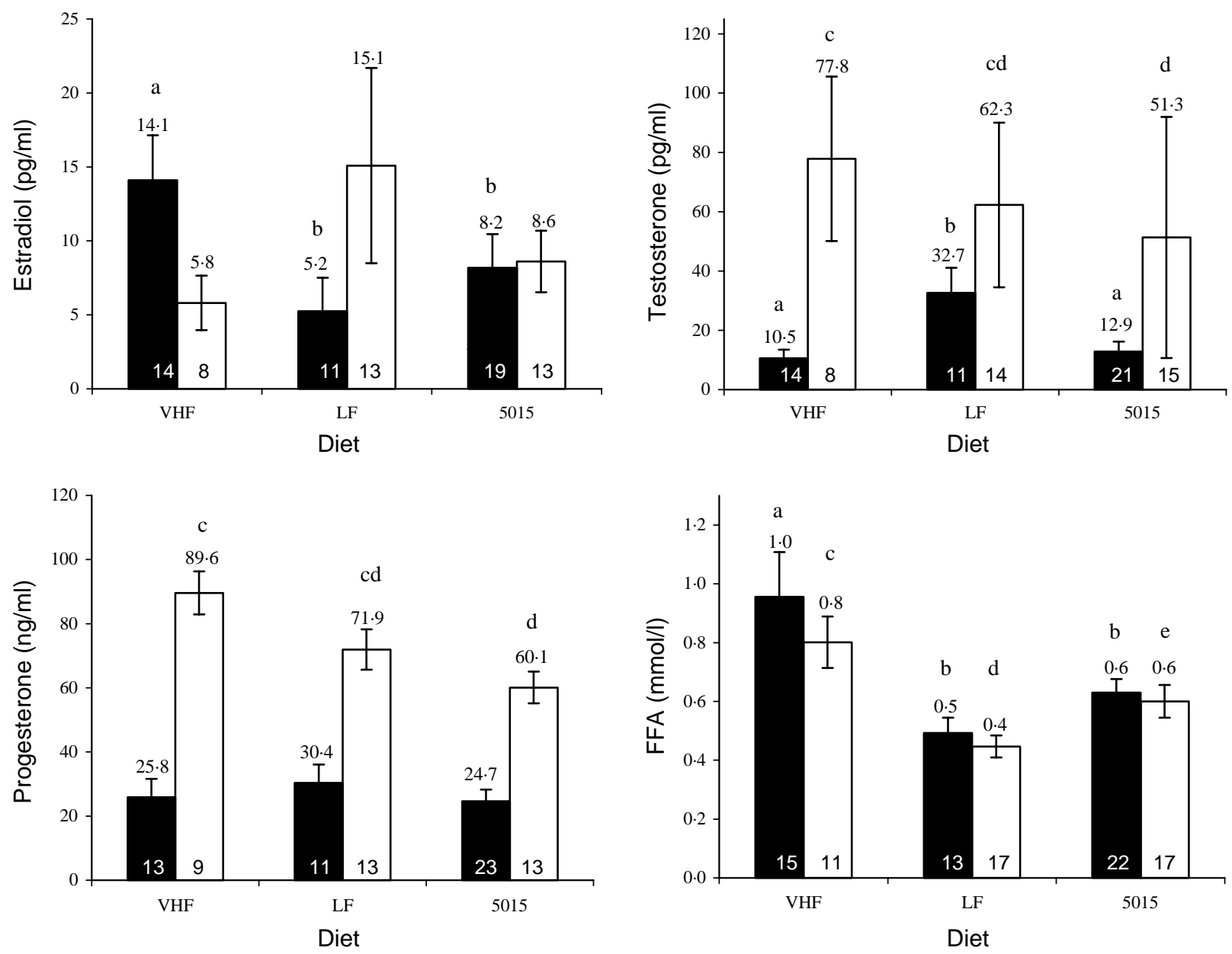

Figure 2 Steroid hormone concentrations (estradiol, testosterone, and progesterone) and free fatty acid (FFA) concentrations at $0 \cdot 5$ (black bars) and $8.5 \mathrm{dpc}$ (open bars) in serum of female NIH Swiss mice maintained on very high fat (VHF), low fat (LF), and control (5015) diets for 16 weeks. Lowercase letters denote significant differences among dietary treatments within the 0.5 and $8 \cdot 5 \mathrm{dpc}$ results $(P \leq 0 \cdot 05)$ for each endpoint. Female sample size is denoted within each bar and the mean concentration for each group is denoted above each bar.

Adipose tissue is the major tissue site of conversion of androstenedione to estrone, and estradiol has been reported to be elevated in obese humans and non-human primates (reviewed in Siiteri 1987, Dieudonne et al. 2006). Maternal body weight was higher overall in the VHF mice in this study (Fig. 1) and an earlier study (Rosenfeld et al. 2003), and the extra visceral fat in these mice probably provided an additional estrogen source. Analogous dietary interventions exert similar effects on circulating estrogen concentrations. Rats fed a diet enriched with $n-3$ FFA had higher estrogen concentrations than their counterparts fed a normal, non-supplemented diet (Hilakivi-Clarke et al. 2002, Fernandez- Twinn et al. 2003). Conversely, nutritionally restricted cattle had lower estrogen concentrations at day 200 of pregnancy than controls (Killen et al. 1989). A meta-analysis of studies in women suggested that increased dietary fat intake resulted in elevated serum estradiol concentrations (Wu et al. 1999, 2000). Finally, Dorgan et al. (2003) noted that a 5-year reduction in dietary fat in pre-pubertal girls reduced serum estradiol (measured at the follicular phase) but increased serum testosterone concentrations (measured at the luteal phase). Whether the amount of accumulated body fat is the main variable in the above studies is unclear. As reviewed by Lambrinoudaki et al. (2006), there have been conflicting reports in women as to whether high serum estrogens are positively correlated with circulating cholesterol and triglyceride concentrations. Species variation and interaction of diet and timing of the estrous or menstrual cycle might account for these seemingly disparate results.

At $0.5 \mathrm{dpc}$, the three groups (VHF, LF, and 5015 controls) had very different $E / T$ ratios. The VHF group, in particular, had relatively high estradiol values and somewhat reduced testosterone values relative to the 5015 controls, whereas the LF-fed mice had elevated circulating testosterone concentrations. Clearly, the relative concentration of the two sex steroids is affected by diet. As discussed above, the low 
testosterone and high estradiol concentrations in VHF females at $0.5 \mathrm{dpc}$ may reflect an increased conversion of androgen to estrogen in adipose tissue. The relatively higher testosterone concentrations in the LF-fed females at $0.5 \mathrm{dpc}$ is seemingly harder to explain but is consistent with Dorgan et al. (2003) findings that girls fed a reduced calorie diet had higher testosterone concentrations, suggesting that a reduced adipose tissue mass results in a buildup of androgen. In serum collected at $8 \cdot 5 \mathrm{dpc}$, the $E / T$ relationship between VHF and LF groups was reversed, in large part because of the increased concentration of testosterone and the reduction of estradiol in the VHF-fed mice. The excess of circulating cholesterol, as would be anticipated in mice on a diet rich in saturated fat, might account for the relatively high concentrations of progesterone and its downstream metabolite, testosterone (Arensburg et al. 1999) in the VHF group at $8.5 \mathrm{dpc}$

It remains to be determined whether these differences in steroid concentrations could influence the sex ratio of pups. Male fetuses have been proposed to be more sensitive to progesterone insufficiency than females (Flint et al. 1997). However, the concentration of this hormone did not differ significantly between the VHF and the LF groups at either 0.5 or $8.5 \mathrm{dpc}$. Moreover, values in the LF group at $8.5 \mathrm{dpc}$ were not different from those measured in the controls. Clearly, progesterone is an unlikely mediator of sex ratio skewing in this case.

Androgens are known to exert epigenetic effects on the developing fetus. For example, female mice born between two males (2M) tend to be masculinized and have more male offspring (Vandenbergh \& Huggett 1995, Vom Saal et al. 1999). Dominant women with elevated serum testosterone concentrations are reported to have significantly more sons than submissive females with lower testosterone concentrations (Grant 1994, Singh \& Zambarano 1997, Grant \& France 2001), and James (1990) has implicated high testosterone concentrations in the mother around the time of conception as a factor likely to favor sons. However, our data show that the mice on the LF diet unexpectedly had the highest testosterone concentrations at $0.5 \mathrm{dpc}$ and had roughly similar concentrations to the VHF group at $8.5 \mathrm{dpc}$. Since mature LF females produce more female than male pups, testosterone seems to be an unlikely mediator of the skewing towards male pups in mice on the VHF diet.

Another difference between mice on the VHF and the LF diets was the concentration of circulating FFA. At $8.5 \mathrm{dpc}$, in particular, serum FFA was higher in the VHF group, a perhaps not surprising outcome, considering that these mice were consuming almost sixfold more calories from fat than the LF group. Little is known about the effects of FFA on the developing embryo and whether there is any sexual dimorphism with regard to either their utilization or relative toxicity. Nor is it clear whether FFA could influence the properties of $\mathrm{X}$ and $\mathrm{Y}$ sperm in some selective manner. The lower vaginal $\mathrm{pH}$ of mice on the VHF diet might be an outcome of their higher circulating concentrations of FFA or estrogen (Gorodeski et al. 2005). Moreover, the motility of X and Y sperm may be influenced by vaginal $\mathrm{pH}$ (Ericsson 1976, Pratt et al. 1987), with more acid conditions providing an advantage to Y-bearing sperm. In hamsters, more male births occur if fertilization occurs late in estrus, possibly as the result of low vaginal $\mathrm{pH}$ (Pratt et al. 1987).

Studies in opossums and humans have implicated elevated dietary FFA, and particularly the essential polyunsaturated fatty acids (PUFA), in increasing male births (Austad \& Sunquist 1986). The presence of excessive lard in the VHF diet, which leads to more male births, could conceivably provide a sparing effect on metabolism of PUFA by mice in the VHF diet group, if indeed PUFA are important in controlling sex ratio, e.g. by altering the production of reproductively significant prostaglandins (PGs), such as PGE or $\mathrm{PGF}_{2 \alpha}$ (Thatcher et al. 1995). To examine the effects of PUFA, we are beginning a study to determine whether diets differing in PUFA but equivalent in total fat calorie content are able to cause a change in sex ratio among pups born to NIH Swiss mice.

To determine whether, indeed, a potential linkage exists between steroid concentrations at the time of conception and alteration of sex ratio, we collected all of the 1-cell embryos at $0 \cdot 5 \mathrm{dpc}$ from the mice in the third study $(n=14$ dams one the LF diet and $n=10$ for dams on the VHF diet). All of their embryos were cultured to the blastocyst stage and the gender of each was determined by XY-FISH analysis with probes from Open Biosystems (Huntsville, AL, USA). The preliminary results from this study suggest that a sex ratio skewing is already present at $0.5 \mathrm{dpc}$ with an increased ratio of male blastocysts in the VHF group and more female blastocysts in the LF group, as determined by the GENMOD procedure in SAS and logit transformation (odds ratio) $(P \leq 0 \cdot 01)$. Further studies will need to be performed to confirm these preliminary results and determine whether the differences in the sex steroids and FFA concentrations at this time point in gestation underpin this putative skewing in sex ratio.

In summary, the amount of fat in the diet fed to female mice, particularly around the time of early diestrus (conception) and mid-diestrus (after conceptus implantation), can influence the circulating concentrations of sex steroids, FFA, and vaginal $\mathrm{pH}$ in those mice on the VHF diet.

\section{Acknowledgements}

The authors are very grateful for the advice and support of Dr R Michael Roberts (University of Missouri-Columbia). The authors would like to thank Dr Elizabeth Parks (University of Minnesota, MN) for advice related to FFA determination. Assistance with animal husbandry and surgery was provided by Dr Jaime Riley, Mr Cory Weimer, and Ms Emily Kern, University of Missouri-Columbia, MO. This study was supported by NIH Grant Number HD044042-02 to Dr R Michael Roberts and C S R. The authors declare that there is no conflict of interest that would prejudice the impartiality of this scientific work. 


\section{References}

Arensburg J, Payne AH \& Orly J 1999 Expression of steroidogenic genes in maternal and extraembryonic cells during early pregnancy in mice. Endocrinology $1405220-5232$.

Austad S \& Sunquist M 1986 Sex-ratio manipulation in the common opossum. Nature 324 58-60.

Belanger C, Luu-The V, Dupont P \& Tchernof A 2002 Adipose tissue intracrinology: potential importance of local androgen/estrogen metabolism in the regulation of adiposity. Hormone and Metabolic Research 34 737-745.

Dieudonne MN, Sammari A, Dos Santos E, Leneveu MC, Giudicelli Y \& Pecquery R 2006 Sex steroids and leptin regulate 11beta-hydroxysteroid dehydrogenase I and $\mathrm{P} 450$ aromatase expressions in human preadipocytes: sex specificities. Journal of Steroid Biochemistry and Molecular Biology 99 189-196.

Dorgan JF, Reichman ME, Judd JT, Brown C, Longcope C, Schatzkin A, Forman M, Campbell WS, Franz C, Kahle L et al. 1996 Relation of energy, fat, and fiber intakes to plasma concentrations of estrogens and androgens in premenopausal women. American Journal of Clinical Nutrition 64 25-31.

Dorgan JF, Hunsberger SA, McMahon RP, Kwiterovich PO Jr, Lauer RM, Van Horn L, Lasser NL, Stevens VJ, Friedman LA, Yanovski JA et al. 2003 Diet and sex hormones in girls: findings from a randomized controlled clinical trial. Journal of the National Cancer Institute 95 132-141.

Ericsson RJ 1976 X and Y spermatozoa. Contraception, Fertilité, Sexualité 4 655-668.

Fernandez-Twinn DS, Ozanne SE, Ekizoglou S, Doherty C, James L, Gusterson B \& Hales CN 2003 The maternal endocrine environment in the low-protein model of intra-uterine growth restriction. British Journal of Nutrition $90815-822$.

Flint AP, Albon SD \& Jafar SI 1997 Blastocyst development and conceptus sex selection in red deer Cervus elaphus: studies of a free-living population on the Isle of Rum. General and Comparative Endocrinology 106 374-383.

Gorodeski GI, Hopfer U, Liu CC \& Margles E 2005 Estrogen acidifies vaginal $\mathrm{pH}$ by up-regulation of proton secretion via the apical membrane of vaginal-ectocervical epithelial cells. Endocrinology 146 816-824.

Grant VJ 1994 Maternal dominance and the conception of sons. British Journal of Medical Psychology 67 343-351.

Grant VJ \& France JT 2001 Dominance and testosterone in women. Biological Psychology 58 41-47.

Hilakivi-Clarke L, Cho E \& Onojafe I 1996 High-fat diet induces aggressive behavior in male mice and rats. Life Science 58 1653-1660.

Hilakivi-Clarke L, Clarke R, Onojafe I, Raygada M, Cho E \& Lippman M 1997 A maternal diet high in n-6 polyunsaturated fats alters mammary gland development, puberty onset, and breast cancer risk among female rat offspring. PNAS 94 9372-9377.

Hilakivi-Clarke L, Cho E, Cabanes A, DeAssis S, Olivo S, Helferich W, Lippman ME \& Clarke R 2002 Dietary modulation of pregnancy estrogen levels and breast cancer risk among female rat offspring. Clinical Cancer Research 8 3601-3610.

James W 1990 The hypothesized hormonal control of human sex ratio at birth: an update. Journal of Theoretical Biology 143 555-564.

Killen JH, Forrest DW, Byers FM, Schelling GT \& Long CR 1989 Gonadotropin-releasing hormone-induced luteinizing hormone release in heifers: effect of nutrition during gestation. Journal of Theoretical Biology 67 496-500.

Kumagai S, Kai Y \& Sasaki H 2001 Relationship between insulin resistance, sex hormones and sex hormone-binding globulin in the serum lipid and lipoprotein profiles of Japanese postmenopausal women. Journal of Atherosclerosis and Thrombosis 8 14-20.

Lambrinoudaki I, Christodoulakos G, Rizos D, Economou E, Argeitis J, Vlachou S, Creatsa M, Kouskouni E \& Botsis D 2006 Endogenous sex hormones and risk factors for atherosclerosis in healthy Greek postmenopausal women. European Journal of Endocrinology 154 907-916.

McCormack JT \& Greenwald GS 1974 Progesterone and oestradiol-17beta concentrations in the peripheral plasma during pregnancy in the mouse. Journal of Endocrinology 62 101-107.

Menotti A 1999 Diet, cholesterol and coronary heart disease. A perspective. Acta Cardiologica 54 169-172.
Nagata C, Nagao Y, Shibuya C, Kashiki Y \& Shimizu H 2005 Fat intake is associated with serum estrogen and androgen concentrations in postmenopausal Japanese women. Journal of Nutrition $1352862-2865$.

Nelson JF, Felicio LS, Osterburg HH \& Finch CE 1992 Differential contributions of ovarian and extraovarian factors to age-related reductions in plasma estradiol and progesterone during the estrous cycle of C57BL/6J mice. Endocrinology 130 805-810.

Overpeck JG, Colson SH, Hohmann JR, Applestine MS \& Reilly JF 1978 Concentrations of circulating steroids in normal prepubertal and adult male and female humans, chimpanzees, rhesus monkeys, rats, mice, and hamsters: a literature survey. Journal of Toxicology and Environmental Health 4 785-803.

Parks EJ, Schneider TL \& Baar RA 2005 Meal-feeding studies in mice: effects of diet on blood lipids and energy expenditure. Comparative Medicine 55 24-29.

Perry GA, Smith MF \& Geary TW 2004 Ability of intravaginal progesterone inserts and melengestrol acetate to induce estrous cycles in postpartum beef cows. Journal of Animal Science 82 695-704.

Pratt NC, Huck UW \& Lisk RD 1987 Offspring sex ratio in hamsters is correlated with vaginal $\mathrm{pH}$ at certain times of mating. Behavioral and Neural Biology 48 310-316.

Rosenfeld CS, Grimm KM, Livingston KA, Brokman AM, Lamberson WE \& Roberts RM 2003 Striking variation in the sex ratio of pups born to mice according to whether maternal diet is high in fat or carbohydrate. PNAS $1004628-4632$

SAS 1988 SAS SAS/STAT User's Guide. Cary, NC: SAS Institute, Inc.

Shelley JM, Green A, Smith AM, Dudley E, Dennerstein L, Hopper J \& Burger H 1998 Relationship of endogenous sex hormones to lipids and blood pressure in mid-aged women. Annals of Epidemiology 8 39-45.

Siiteri PK 1987 Adipose tissue as a source of hormones. American Journal of Clinical Nutrition 45 277-282.

Simpson ER 2003 Sources of estrogen and their importance. Journal of Steroid Biochemistry and Molecular Biology 86 225-230.

Singh D \& Zambarano RJ 1997 Offspring sex ratio in women with android body fat distribution. Human Biology $69545-556$.

Talavera F, Park CS \& Williams GL 1985 Relationships among dietary lipid intake, serum cholesterol and ovarian function in Holstein heifers. Journal of Animal Science 60 1045-1051.

Thatcher WW, Meyer MD \& Danet-Desnoyers G 1995 Maternal recognition of pregnancy. Journal of Reproduction and Fertility. Supplement 49 15-28.

Vandenbergh J \& Huggett C 1995 Mother's prior intrauterine position affects the sex ratio of her offspring in house mice. PNAS 91 1155-1159.

Vom Saal F, Clark M, Galef B, Drickamer L \& Vandenbergh J 1999 The intrauterine position (IUP) phenomenon. In Encyclopedia of Reproduction, pp 893-900. Eds E Knobil \& J Neill. New York: Academic Press.

Walmer DK, Wrona MA, Hughes CL \& Nelson KG 1992 Lactoferrin expression in the mouse reproductive tract during the natural estrous cycle: correlation with circulating estradiol and progesterone. Endocrinology 131 1458-1466.

Woods MN, Barnett JB, Spiegelman D, Trail N, Hertzmark E, Longcope C \& Gorbach SL 1996 Hormone levels during dietary changes in premenopausal African-American women. Journal of the National Cancer Institute 88 1369-1374.

Wu AH, Pike MC \& Stram DO 1999 Meta-analysis: dietary fat intake, serum estrogen levels, and the risk of breast cancer. Journal of the National Cancer Institute 91 529-534.

Wu AH, Stram DO \& Pike MC 2000 RESPONSE re: meta-analysis: dietary fat intake, serum estrogen levels, and the risk of breast cancer. Journal of the National Cancer Institute 92 78A-78.

Wynn A \& Wynn M 1993 The effects of food shortage on human reproduction. Nutrition and Health 9 43-52.

Zhou Y, Lin S, Chang HH, Du J, Dong Z, Dorrance AM, Brands MW \& Wang MH 2005 Gender differences of renal CYP-derived eicosanoid synthesis in rats fed a high-fat diet. American Journal of Hypertension 18 530-537.

Received in final form 24 October 2006

Accepted 26 October 2006

Made available online as an Accepted Preprint 30 October 2006 